\title{
Correction to: Green's functions and integral representation of generalized continua: the case of orthogonal pantographic lattices
}

Claude Boutin (D) and Francesco dell'Isola

Correction to: Z. Angew. Math. Phys. (2021) 72:58

https://doi.org/10.1007/s00033-021-01480-3

In the original publication of the article, the first and last names of both the authors were swapped. The correct version of the author names is given below:

Claude Boutin . Francesco dell'Isola

The original article has been corrected.

Publisher's Note Springer Nature remains neutral with regard to jurisdictional claims in published maps and institutional affiliations.

\section{Claude Boutin}

Ecole nationale des Travaux publics de l'Etat - Université de Lyon

CNRS UMR 5513

Vaulx-en-Velin

France

e-mail: claude.boutin@entpe.fr

Francesco dell'Isola

Université Aquila - Memocs

L'Aquila

Italy

The original article can be found online at https://doi.org/10.1007/s00033-021-01480-3. 